\title{
Fasilitas dan Lingkungan Kerja Layanan Kesehatan Terhadap Kepuasan pelanggan
}

\author{
Hermanto Hermanto ${ }^{1}$, Tatik Amani ${ }^{2}$, Elok Dwi Vidyastutik ${ }^{3}$, Tedy Herlambang ${ }^{4}$ \\ Universitas Panca Marga ${ }^{1234}$ \\ Email: hermanto@upm.ac.id
}

https://doi.org/10.30741/wiga.v9i2.461

\section{N F O A R T I K E L}

Tanggal masuk :

5 Agustus 2019

Tanggal Revisi :

1 September 2019

Tanggal Diterima :

30 September 2019

\section{A B S T R A K}

Organisasi pelayanan dituntut selalu mengoptimalkan sumber daya yang di kelola guna meningkatkan kepuasan pelanggan, penelitian ini bermaksud menganalisis pengaruh fasilitas (fasilitas langsung dan fasilitas penunjang) layanan kesehatan dan lingkungan kerja ( lingkungan kerja langsung dan kondisi atau cuaca lingkungan kerja) layanan kesehatan terhadap kepuasan pelanggan. Pengambilan data dengan metode survey terhadap 500 responden pengguna layanan kesehatan pada Pusat Kesehatan Masyarakat di Kabupaten Probolinggo, dengan metode kuantitatif data dianalisis dengan uji t dalam regresi. Hasil penelitian telah menunjukan bahwa fasilitas kerja langsung dan fasilitas penunjang serta lingkungan kerja langsung pelayanan kesehatan telah memberikan kontribusi yang positip terhadap kepuasan pelanggan, sedangkan lingkungan kerja yang berkaitan dengan kondisi atau cuaca lingkungan yang diukur dengan indikator kebisingan, polusi udara, dan penerangan di tempat pelayanan belum sepenuhnya berkontribusi terhadap kepuasan pelanggan, sehingga lingkungan kerja yang berkaitan dengan kondisi cuara perlu mendapat perhatian atau solusi peningkatan pelayanan guna memenuhi kepuasan pelanggan, dan hal ini perlu memperhatikan lokasi tempat pelayanan Pusat Kesehatan Masyarakat di Kabupaten Probolinggo yang berdekatan dengan jalan raya.

Kata kunci: Fasilitas layanan, Lingkungan Kerja Layanan dan Kepuasan Pelanggan. 
to pay attention to the location of the Community Health Center services in Probolinggo Regency, which is close to the highway.

Keywords: Service facilities, Service Work Environment and Customer Satisfaction.

\begin{abstract}
PENDAHULUAN
Organisasi pelayanan dituntut untuk dapat mengoptimalkan sumber daya layanan yang dikelolanya. Pengelolaan sumber daya layanan tidak lepas dari faktor tenaga kerja, fasilitas, lingkungan kerja layanan dan lainnya yang diharapkan dapat memberikan layanan sebaik mungkin demi mencapai tujuan dan kemajuan organisasi. Fasilitas layanan bagi organisasi pelayanan merupakan aset utama organisasi, dan mempunyai peran yang strategis didalam organisasi yaitu sebagai sarana, prasarana, alat dan tempat pengendali aktivitas organisai, fasilitas dan lingkungan kerja organisasi layanan tercermin didalam adanya gedung, tempat, sarana prasarana, alat, kelengkapan, layanan pendukung dan keadaan lingkungan sekitarnya (Hermanto, 2016a; Sofyan dkk, 2013) lingkungan kerja yang baik akan mendukung pelayanan dan kepuasan pelanggan, Kepuasan pelanggan dalam pemberian layanan kesehatan, faktor-faktor seperti interaksi, kualifikasi, keterjangkauan keuangan, lingkungan, aksesibilitas fisik, dokter yang memadai, kerahasiaan, penetapan harga, korupsi dan karakteristik sosial-demografi (Jiang et al., 2009)
\end{abstract}

Melihat pentingnya fasilitas dan lingkungan kerja dalam organisasi pemberi pelayanan, maka petugas pelayanan diperlukan perhatian lebih serius terhadap tugas yang dikerjakan sehingga kepuasan pelanggan tercapai. Salah satu caranya adalah meningkatkan kinerja pelayanan, dan kualitas layanan berpengaruh terhadap kepuasan pelanggan (Elfian \& Ariwibowo, 2018; Gofur, 2019; Herokholiqi, 2018; Hidayat, 2018; Meesala \& Paul, 2016; Sofyan dkk, 2013; Widodo, 2016) banyak faktor yang dapat mempengaruhi kinerja pelayanan, antara lain, peningkatan kompetensi dengan diberi pelatihan, pemgembangan keahlian, pendidikan, rotasi kerja, magang, promosi, job enrichment dll, (Ansory dan Indrasari, 2018), kompetensi petugas layanan bisa optimal apabila di dukung dengan fasilitas dan peralatan pelayanan yang baik dan memadai interaksi, kualifikasi, keterjangkauan keuangan, lingkungan, aksesibilitas fisik, dokter yang memadai, kerahasiaan, penetapan harga, korupsi dan karakteristik sosial-demografi (Jiang et al., 2009).

Fasilitas pendukung kinerja pelayanan meliputi tersedianya gedung tempat bekerja, meja, kursi, komputer, mobil dinas, musholla, toilet dll, fasilitas pelayanan kesehatan merupakan alat atau tempat yang di gunakan sebagai upaya untuk menyelenggarakan pelayanan kesehatan (UU RI No.36, 2009) penyediaan fasilitas dan lingkungan kerja layanan yang baik kinerja karyawan akan lebih baik (Lestary, 2018; Sudiarditha, 2016; Sulistiawan, 2017) tentu akan meningkatkan mutu layanan yang akan berdampak pada kepuasan pelanggan (Sofyan dkk, 2013) secara umum kepuasan pelanggan tidak cukup hanya terpenuhinya fasilitas yang baik tetapi ada faktor lain yang dapat meningkatkan kepuasan yaitu faktor lingkungan sekitarnya, lingkunggan pisik berpengaruh terhadap kesenangan dan kepuasan pelanggan (Ali et al, 2016). Oleh karena itu organisasi layanan harus mengelola dan menetapkan fasilitas dan lingkungan kerja untuk memenuhi persyaratan dan kesesuaian layanan yang dibutuhkan (ISO 9001, 2015) dan lingkungan kerja adalah segala sesuatu yang ada di sekitar pekerja yang dapat mempengaruhi pelayanannya, (Sari, 2016) yang memberikan keamanan dan kenyamanan bagi pekerja dan pelanggan dalam interakasi pelayanan yaitu hubungan yang baik dan harmonis antar tenaga kerja dan konsumennya, sehingga lingkungan kerja yang baik akan berdampak pada kepuasan kerja karyawan (Azhar, 2018; Rahayuningsih, 2017; Ratihpratiwi, 2019; Virgana, 2014; Warsito, 2008) dan kepuasan pelanggan akan tetap terjaga.

Kepuasan pelanggan adalah evaluasi awal dan kinerja aktual jasa layanan di persepsikan setelah pemerolehan layanan Day dalam (Tjiptono \& Chandra, 2011) dan pengalaman layanan atau konsumsi hendaknya sesuai dengan yang di harapkan Hunt dalam (Tjiptono \& Chandra, 2011) 
Kepuasan pelanggan dapat terpenuhi melalui kualitas pelayanan (Hidayat, 2018) yang baik dan beberapa faktor dan keadaan, dari uraian diatas menggambarkan betapa pentingnya fasilitas layanan dan lingkungan sekitarnya termasuk lingkungan pisik (Ali et al, 2016) mempunyai andil terhadap terhadap kesenangan dan kepuasan pelanggan.

Dari uraian diatas kepuasan pelanggan banyak di jabarkan hanya melalui servis kualitas sedangkan fasilitasn belum terbahas secara khusus begitu juga lingkungan kerja hanya banyak di uraikan di pada tingkatan kepuasan dan kinerja karyawan atau petugas pelayanan dari sini mengindikasikan bahwa fasilitan dan lingkungan kerja layanan belum ada yang melakukan penelitian secara tersendiri oleh karena itu peneliti tertarik untuk melakukan penelitian secara khusus hanya terkait dengan fasilitas kerja dan lingkungan kerja layanan, dengan rumusan sejauh mana fasilitas dan lingkungan kerja layanan berpengaruh terhadap kepuasan pelanggan?. Adapun tujuan dari penelitian ini dimaksudkan untuk menganalisis fasilitas kerja layanan kesehatan (fasilitas langsung dan fasilitas Penunjang) dan lingkungan kerja layanan (lingkungan kerja langsung dan kondisi atau cuaca) kesehatan pengaruhnya terhadap kepuasan pelanggan. Hipotesis yang disusun berdasarkan penelitian sebelumnya bahwa fasilitas kerja (fasilitas langsung dan fasilitas Penunjang) layanan kesehatan dan lingkungan kerja (lingkungan kerja langsung dan kondisi atau cuaca) layanan kesehatan berpengaruh positif dan signifikan terhadap kepuasan pelanggan.

Organisasi harus menetapkan, menyediakan dan memelihara fasilitas yang dibutuhkan untuk mencapai kesesuaian persyaratan produk atau layanan, fasilitas termasuk sebagaimana yang diberlakukan pada Gedung, ruang kerja dan sarana terkait, Peralatan proses dan layanan pendukung lainnya, (Hermanto, 2016a; ISO 9001, 2015). Fasilitas yang berkaitan dengan pekerjaan yaitu suatu sarana fisik yang dapat memproses suatu masukan (input) menuju keluaran (output) yang di inginkan, dan ketersediaan fasilitas-fasilitas tersebut dapat memperlancar pekerjaan dan menyenangkan bagi penggunanya misalnya fasilitas tempat ibadah, jaminan pengobatan, jaminan hari tua dan lain sebagainya. (Sari, 2016), Fasilitas ialah segala sesuatu yang digunakan, dipakai, ditempati dan dinikmati oleh pekerja baik dalam hubungan langsung dengan pekerjaan maupun untuk kelancaran pekerjaan (Salgiarti \& Suryani, 2017) yang dapat dipakai sebagai alat dalam mancapai maksud atau tujuan organisasi.

Keberadaan sarana dan prasrana institusi pelayanan menjadi sangat penting sebagai fasilitas dalam melaksanakan pekerjaan, terutama dalam kegiatan operasional pelayanan (Priansa, 2017) sedangkan fasilitas di organisasi pelayanan kesehatan adalah meliputi alat kerja yang berhubungan langsung dengan pelanggan meliputi intrumen, aparatus, mesin, inplan dan lainnya (Permenkes No. 71, 2013) dan fasilitas kelengkapan penunjang seperti toilet, tempat parkir, kantin, tempat ibadah dan lainnya. Indikator fasilitas kerja menjadi dua golongan besar yaitu meliputi; 1). Fasilitas alat kerja, yang merupakan semua benda yang atau barang yang berfungsi sebagai alat kerja yang secara langsung digunakan dalam produksi atau pelayanan. 2). Fasilitas penunjang perlengkapan kerja, adalah semua benda, barang atau tempat yang digunakan dalam pekerjaan tetapi tidak langsung untuk berproduksi melainkan berfungsi sebagai pelancar dan penyegar dalam pekerjaan (Salgiarti \& Suryani, 2017).

Organisasi atau institusi harus menetapkan dan mengelola lingkungan kerja yang diperlukan untuk mencapai kesesuaian dengan persyaratan produk. Yang dimaksud Istilah "Lingkungan kerja" berhubungan dengan kondisi saat pekerjaan dilakukan termasuk fisik, lingkungan dan faktor lainnya, seperti kebisingan, temperatur, kelembaban, penerangan atau cuaca (ISO 9001, 2015). Lingkungan kerja adalah segala sesuatu yang ada di sekitar karyawan dan dapat mempengaruhi dalam menjalaknan tugas yang diembankan kepadanya (Afandi, 2018), keseluruhan alat perkakas dan bahan yang dihadapi lingkungan sekitarnya di mana seseorang bekerja, metode kerjanya serta pengaturan kerjanya baik sebagai perseorangan maupun sebagai kelompok dan segala sesuatu yang ada disekitar para pekerja yang dapat mempengaruhi dirinya dalam menjalankan tugas-tugas yang diembankan (Sari, 2016) 
Lingkungan kerja dapat dibagi dalam dua kategori, yaitu lingkungan kerja fisik dan lingkungkan kerja nonfisik, untuk memperkecil pengaruh lingkungan fisik terhadap pegawai maka langkah pertama adalah harus mempelajari manusia, baik mengenai sifat dan tingkah lakunya maupun mengenai fisiknya, kemudian digunakan sebagai dasar memikirkan lingkungan fisik yang sesuai (Sedarmayanti, 2011). Lingkungan kerja fisik maupun nonfisik keduanya sama pentingnya dalam sebuah organisasi, kedua lingkungan kerja ini tidak bisa dipisahkan. Apabila sebuah perusahaan hanya mengutamakan satu jenis lingkungan kerja saja, tidak akan tercipta lingkungan kerja yang baik, dan lingkungan kerja yang kurang baik dapat menuntut tenaga kerja dan waktu yang lebih banyak dan tidak mendukung diperolehnya rancangan sistem kerja yang efisien dan akan menyebabkan organisasi tersebut mengalami penurunan produktivitas kerja (Afandi, 2018). Pada organisasi pemberi layanan akan berdampak pada kualitas layanan yang diberikan dan kepuasan pelanggan akan berpengaruh.

Aspek Lingkungan Kerja nonfisik yang dapat mempengaruhi prilaku pekerja yaitu; struktur kerja, Tanggung jawab kerja, Perhatian dan dukungan, Kerja sama antar kelompok, dan Kelancaran komunikasi, Sejauh mana seorang pekerja merasakan adanya komunikasi yang bebas, terbuka, lancar dan komunikasi yang baik antara pekerja, atasan dan bawahan atau komunikasi antar pekerja dengan pelanggan (Setyawan, 2017) lingkungan kerja fisik dan nonfisik yang dapat memberikan kepuasan, keamanan kenyamanan bagi pekerja dan lingkungan sekitarnya (Afandi, 2018). Lingkungan fisik yang baik akan merangsang pelanggan mempunyai beli dan kepuasan dan terhadap pekerja akan membentuk perilaku mereka untuk bekerja yang lebih baik sehingga ini merupakan komponen yang penting untuk membentuk kepuasan pelanggan, Ryu dalam (Ali et al, 2016)

Kepuasan adalah respons emosional yang ditunjukkan oleh konsumen setelah proses pembelian atau pelayanan yang di konsumsi berasal dari perbandingan antara kinerja aktual terhadap harapan serta evaluasi pengalaman mengonsumsi produk atau layanan (Ningsih \& Segoro, 2014), dan merupakan evaluasi dimana yang dipilih yang sekurang-kurangnya atau melampaui harapan pelanggan, sedangkan ketidakpusan timbul apabila hasil (autcome) tidak memenuhi harapan, Engel dalam (Tjiptono \& Chandra, 2015). Organisasi yang bergerak di bidang layanan, kepuasan pelanggan merupakan bagian dari indikator dari hasil kinerja yang diinginkan. Perfomance atau kinerja adalah hasil kerja yang dapat dicapai oleh seseorang atau kelompok orang dalam suatu perusahaan sesuai dengan wewenang dan tanggung jawab masing-masing dalam upaya pencapaian tujuan organisasi secara legal, tidak melanggar hukum dan tidak bertentangan dengan moral dan etika (Afandi, 2018).

Mengidentifikasi dimensi-dimensi kunci kepuasan pelanggan dapat dilakukan dengan meminta pelanggan menilai produk atau jasa bedasarkan item spesifik seperti kecepatan petugas pelayanan, fasilitas pelayanan, atau keramahan petugas pelayanan, Kotler dalam (Tjiptono \& Chandra, 2015). Konsep kepuasan secara umum ada dua; yang pertama adalah konsep kepuasan secara spesifik dimana berkaitan dengan pembelian atau penggunaan produk layanan tunggal, yang kedua adalah kepuasan secara keseluruhan dimana berkaitan dengan pembelian penggunaan produk layanan secara berulang dan memberikan pengalaman dari waktu ke waktu yang akhirnya membentuk loyalitas pelanggan, Woodside dalam (Meesala \& Paul, 2016)

\section{METODE PENELITIAN}

Metode penelitian yang digunakan adalah jenis penelitian kuantitatif dengan pendekatan deskriptif. Adalah jenis penelitian yang menghasilkan penemuan-penemuan yang dapat dicapai dengan menggunakan prosedur-prosedur statistik atau cara-cara lain dari kuantifikasi (Sujarweni, 2014) Populasinya adalah keseluruhan jumlah pelanggan yang mendapatkan layanan kesehatan di Pusat Kesehatan Masyarakat Leces Kabupaten Probolinggo selama kurun waktu 3 bulan di tahun 2019 dengan teknik purposive sampling 500 responden sebagai pengumpulan data primer melalui 
kuesioner yang telah memenuhi syarat uji validitas dan reliabilitas. Metode analisis data dalam penelitian ini menggunakan pendekatan uji t kuantitatif berupa analisis regresi berganda.

Variabel yang digunakan dalam penelitian ini terdiri dari variabel bebas dan variabel terikat, variabel bebas $(\mathrm{X})$ adalah variabel Fasilitas dan Linkungan kerja yang mempengaruhi variabel terikat (Y) Kepuasanan pelanggan. Variabel $\mathrm{X}_{1}$ (Fasilitas) terdiri dari Fasilitas langsung $\left(\mathrm{X}_{11}\right)$ berhubungan dengan layanan pelanggan yang diukur dengan (layanan obat, layanan laboratorium, alat-alat layanan dan ruang tunggu) dan Fasilitas penunjang $\left(\mathrm{X}_{12}\right)$ sebagai kelengkapan pelayanan yang diukur dengan (ambulance, tempat parkir, tempat ibadah dan toilet). Variabel $\mathrm{X}_{2}$ (Lingkungan kerja) Lingkungan langsung $\left(\mathrm{X}_{21}\right)$ yang diukur dengan (hubungan dan komunikasi petugas dengan pelanggan, kenyamanan dan keamanan layanan dan kebersihan lingkungan) dan Kondisi lingkungan/cuaca $\left(\mathrm{X}_{22}\right)$ yang diukur dengan (Kebisingan suara, polusi udara dan penerangan lampu). Variabel Y (Kepuasan pelanggan) yang diukur dengan (layanan secara keseluruhan, harapan pelanggan, mutu layanan, penanganan keluhan dan pengaduan). Data penelitian yang digunakan berasal dari kuesioner, dengan skala likert (1 sampai dengan 5) sebagai pengukuran sikap, pendapat, dan persepsi responden dari item-item pertanyaan (Sujarweni, 2014)

\section{HASIL DAN PEMBAHASAN}

Penelitian ini dilakukan di Pukesmas Leces kabupaten Probolinggo yang telah mendapatkan sertifikasi akreditasi pelayanan sehingga hasil penelitian ini sangat bermanfaat sebagai salah satu evaluasi kinerja layanan, metode penelitian ini menggunakan kuesioner dengan 500 responden dengan karakteristik sebagai berikut:

Tabel 1. Karakteristik Responden

\begin{tabular}{|c|c|c|c|c|c|c|c|}
\hline \multirow{2}{*}{\multicolumn{4}{|c|}{ Jenis Kelamin }} & \multirow{2}{*}{\multicolumn{4}{|c|}{ Umur }} \\
\hline & & & & & & & \\
\hline Nomor & Sex & Frequency & Percent & Nomor & Age & Frequency & Percent \\
\hline 1 & Laki-laki & 141 & 28,2 & 1 & $16-25$ & 131 & 26,2 \\
\hline 2 & Perempuan & 352 & 70,4 & 2 & $26-35$ & 135 & 27,0 \\
\hline \multirow[t]{5}{*}{3} & Tidak jelas & 7 & 1,4 & 3 & $36-45$ & 160 & 32,0 \\
\hline & Total & 500 & 100,0 & 4 & $46-55$ & 50 & 10,0 \\
\hline & & & & 5 & $56-<$ & 19 & 3,8 \\
\hline & & & & 6 & $\begin{array}{l}\text { Tidak } \\
\text { jelas }\end{array}$ & 5 & 1,0 \\
\hline & & & & & Total & 500 & 100,0 \\
\hline \multicolumn{4}{|c|}{ Pekerjaan } & \multicolumn{4}{|c|}{ Pendidikan } \\
\hline Nomor & Job & Frequency & Percent & Nomor & Education & Frequency & Percent \\
\hline 1 & PNS & 9 & 1,8 & 1 & $\mathrm{SD}$ & 111 & 22,2 \\
\hline 2 & TNI/Polri & 2 & ,4 & 2 & SLTP & 106 & 21,2 \\
\hline 3 & Kary Swasta & 89 & 17,8 & 3 & SLTA & 214 & 42,8 \\
\hline 4 & Wiraswasta & 124 & 24,8 & 4 & Diploma & 23 & 4,6 \\
\hline 5 & Tani & 123 & 24,6 & 5 & Sarjana & 28 & 5,6 \\
\hline \multirow[t]{2}{*}{6} & Tidak jelas & 153 & 30,6 & 6 & $\begin{array}{l}\text { Tidak } \\
\text { jelas }\end{array}$ & 18 & 3,6 \\
\hline & Total & 500 & 100,0 & & Total & 500 & 100,0 \\
\hline
\end{tabular}

Sumber: Data diolah, 2019 
Dari hasil pengolahan data karakteristik responden didapat 70,4\% adalah perempuan, mayoritas pekerjaan tidak disebutkan, umur antara 36-45 tahun 32,0\%, sedangkan karakteristik pekerjaan yang tidak disebutkan $30,6 \%$ dan pendidikan rata-rata SLTA $42,8 \%$.

Tabel 2. Uji Validitas \& Reliabilitas

\begin{tabular}{|c|c|c|c|c|c|}
\hline Item & $\begin{array}{l}\mathrm{r}- \\
\text { hitung }\end{array}$ & $\begin{array}{l}\text { Cronbach's } \\
\text { Alpha }\end{array}$ & Item & $\begin{array}{l}\mathrm{r}- \\
\text { hitung }\end{array}$ & $\begin{array}{l}\text { Cronbach's } \\
\text { Alpha }\end{array}$ \\
\hline Keamananlayanan & ,683** & & Kebisingan & ,828** & \\
\hline Nyaman &, $741 * *$ & & Polusiudara &, $835 * *$ & \\
\hline Kebersihan &, $663 * *$ & & Penerangan &, $684 * *$ & \\
\hline Komunikasipetugas &, $725 * *$ & & Kondisicuaca & 1 & 0,683 \\
\hline Sampah &, $594 * *$ & & & & \\
\hline Lingklangsung & 1 & 0,816 & & & \\
\hline Laboratorium & ,792** & & Toilet & ,677** & \\
\hline Obat &, $822 * *$ & & Ambulance &, $782 * *$ & \\
\hline Alatpelayanan &, $792 * *$ & & Parkir &, $720 * *$ & \\
\hline Ruangtunggu &, $783 * *$ & & Fasibadah &, $742 * *$ & \\
\hline \multirow[t]{2}{*}{ Fasilangsung } & 1 & 0,799 & Faslain &, $728 * *$ & \\
\hline & & & Fasipenunjang & 1 & 0,719 \\
\hline
\end{tabular}

\begin{tabular}{ll} 
hasillayanan &, $761 * *$ \\
Keluhan &, $806 * *$ \\
Harapan &, $797 * *$ \\
Layananpetugas &, $781 * *$ \\
kualitaslayanan &, $822 * *$ \\
\hline Kepuasan & 1 \\
\hline$* *$ Correlation is significant at the 0.01 level (2-tailed). \\
Sumber: Data diolah, 2019
\end{tabular}

Dari hasil uji validitas dan reliabilitas menunjukan semua item pertanyaan dalam kuesioner yang digunakan untuk mengukur variabel adalah valid dan handal.

Uji t di lakukan untuk menguji hipotesis dan analisis koefisien regresi untuk menganalisis besarnya pengaruh variabel bebas terhadap variabel terikat menggunakan aplikasi spss yaitu variabel fasilitas dengan dimensi fasilitas langsung dan fasilitas penunjang, variabel lingkungan kerja dengan dimensi lingkungan langsung dan kondisi lingkungan kerja (cuaca) pengaruhnya terhadap kepuasan pelanggan didapatkan hasil sebagai berikut:

Tabel 3. Uji t

\begin{tabular}{llllll}
\hline Nomor & Variabel & t-tabel & t-hitung & Sig. & Keterangan \\
\hline 1 & Fasilitas langsung & & 3,690 & 0,000 & Ya \\
2 & Fasilitas penunjang & \multirow{2}{*}{1,648} & 3,634 & 0,000 & Ya \\
3 & Kondisi cuaca & & 0,089 & 0,929 & Tidak \\
4 & Lingkungan langsung & & 12,013 & 0,000 & Ya \\
\hline
\end{tabular}

Sumber: Data diolah, 2019 
Tabel 4. koefisien regresi

\begin{tabular}{llllll}
\hline Nomor & Variabel & B & Beta & Sig. & Keterangan \\
\hline 1 & Konstanta & 0,946 & & 0,276 & \\
2 & Fasilangsung & 0,223 & 0,155 & 0,000 & Positif \\
3 & Fasipenunjang & 0,191 & 0,162 & 0,000 & Positif \\
4 & Kondisicuaca & 0,006 & 0,003 & 0,929 & Positif \\
5 & Linglangsung & 0,556 & 0,484 & 0,000 & Positif \\
\hline
\end{tabular}

Sumber: Data diolah, 2019

Dari hasil uji $\mathrm{t}$ didapat bahwa: Fasilitas langsung yang diukur dengan fasilitas layanan (laboratorium, fasilitas layanan obat, alat-alat layanan langsung dan ruang tunggu), dengan nilai thitung $(3,690)>$ t-tabel $(1,648)$ dengan sig. $(0,000)$ berpengaruh positif dan signifikan terhadap kepuasan pelanggan, sehingga hipotesis yang diajukan di terima. Besarnya koefisien regresi $(0,223)$ positif yang artinya bahwa semakin baik layanan yang berhubungan dengan fasilitas langsung (layanan labortorium, layanan obat, alat-alat layanan dan ruang tunggu) maka kepuasan pelanggan akan semakin baik. Dan Fasilitas penunjang yang diukur dengan fasilitas layanan (ambulance, fasilitas parkir, fasilitas tempat ibadah, fasilitas toilet dan fasilitas lain), dengan thitung $(3,634)>$ t-tabel $(1,648)$ dengan sig. $(0,000)$ berpengaruh positif dan signifikan terhadap kepuasan pelanggan dengan demikian hipotesis yang diajukan juga diterima, Besarnya koefisien regresi $(0,191)$ yang artinya bahwa semakin baik layanan yang berhubungan dengan fasilitas penunjang (fasilitas layanan ambulance, fasilitas tempat parkir, fasilitas tempat ibadah, fasilitas toilet dan fasilitas lain) maka kepuasan pelanggan akan semakin terpenuhi.

Dari hasil uji t dan analisis regresi kedua fasilitas langsung dan fasilitas penunjang berpengaruh positif terhadap kepuasan pelanggan ini sejalan dengan hasil penelitian (Sofyan dkk, 2013) bahwa fasilitas berpengaruh terhadap kepuasan konsumen, begitu juga penelitian (Ismail, 2001; Soekiyono, 2017) yang mengukur fasilitas melalui dimensi tangible pada kualitas layanan juga memberikan kontribusi yang positif terhadap kepuasan dan loyalitas pelanggan, tetapi sebaliknya dengan hasil penelitian (Miswanto, 2017) bahwa fasilitas yang diukur melalui dimensi tangible pada kualitas layanan tidak mempunyai pengaruh positif terhadap kepuasan konsumen, ini menggambarkan masih ada gap hasil penelitian yang berkaitan dengan fasilitas layanan.

Lingkungan kerja layanan langsung yang diukur dengan (keamanan dan kenyaman layanan, hubungan dan komunikasi petugas pelayanan dengan pelanggan, kebersihan dan penanganan sampah di lingkungan kerja layanan), dengan t-hitung $(12,013)>$ t-tabel $(1,648)$ dengan sig. $(0,000)$ berpengaruh positif dan signifikan terhadap kepuasan pelanggan sehingga hipotesis yang diajukan diterima. Besarnya koefisien regresi $(0,556)$ positif yang artinya bahwa semakin baik layanan lingkungan kerja yang langsung berhubungan dengan pelayanan pelanggan maka kepuasan pelanggan akan semakin baik, Lingkungan kerja langsung yang merupakan bagian dari interaksi dan komunikasi (Setyawan, 2017) berkaitan dengan tugas-tugas yang diembannya (Afandi, 2018; Sari, 2016) yang membentuk perilaku petugas pelayanan (Ali et al, 2016) dengan pelanggan menjadi hal penting yang dapat memberikan kepuasan pada pelanggan.

Sedangkan kondisi lingkungan kerja layanan (cuaca) yang diukur dengan (polusi udara, kebisingan suara dan penerangan) dengan t-hitung $(0,089)<\mathrm{t}$-tabel dengan sig. $(0,929)$ berpengaruh positif tetapi tidak signifikan terhadap kepuasan pelanggan dan hipotesis yang diajukan ditolak. Besarnya koefisien regresi $(0,006)$ positif artinya bahwa kondisi lingkungan kerja layanan (cuaca) berpengaruh positif tetapi tidak signifikan terhadap kepuasan pelanggan, hal ini kondisi lingkungan kerja (cuaca) yang diukur dengan polusi udara, kebisingan suara dan penerangan tidak sesuai yang diamanatkan dalam (Hermanto, 2016b; ISO 9001, 2015) bahwa manajemen layanan 
harus selalu menjaga kondisi lingkungan fisik untuk menjamin kenyamanan di lingkungan kerja yang akan berdampak pada kualitas layanan (Afandi, 2018), ini dikarenakan memang lokasi pelayanan kesehatan di Puskesmas Leces dekat dengan jalan raya antar kabupaten dimana lalu lintas sangat padat yang kadang meninmbulkan polusi dan kebisingan suara kendaraan.

Dari aspek lingkungan kerja layanan yang diukur dengan dua dimensi lingkungan kerja langsung dan kondisi lingkungan (cuaca) memberikan hasil yang berbeda, aspek dimensi lingkungan kerja langsung memberikan kontribusi yang dominan terhadap kepuasan pelanggan. Namun secara umum dan keseleruhan lingkungan kerja layanan memberikan pengaruh yang positif terhadap kepuasan pelanggan.

Sedangkan besarnya pengaruh secara keseluruhan variabel bebas (Fasilitas langsung, fasilitas penunjang, lingkungan kerja layanan langsung dan kondisi lingkungan kerja layanan) terhadap variabel terikat (kepuasan pelanggan) dapat ditunjukan sebagai berikut:

Tabel 5. Uji F

\begin{tabular}{lllllll}
\hline Nomor & df & R Square & F-tabel & F-hitung & Sig. & Keterangan \\
\hline 1 & 4 & 0,473 & 2,390 & 111,043 &, $000 \mathrm{~b}$ & Positif \\
\hline \multicolumn{7}{l}{ Sumber: Data diolah, 2019 }
\end{tabular}

Secara keseluruhan variabel bebas di kaji dari analisis uji F menunjukkan F-hitung $(111,043)$ lebih besar daripada F-tabel $(2,390)$ dengan sig. $(0,000)$ yang artinya bahwa keseluruhan variabel bebas (fasilitas kerja dan lingkungan kerja layanan) berpengaruh positif terhadap variabel terikat (kepuasan pelanggan) dimana kepuasan pelanggan merupakan pengaruh semua aspek dimensi kinerja layanan (Meesala \& Paul, 2016; Ningsih \& Segoro, 2014) dan besarnya pengaruh adalah 47,3 persen dan sisanya dipengaruhi faktor lain yang tidak masuk dalam penelitian ini.

\section{KESIMPULAN}

Kepuasan pelanggan yang diukur dengan beberapa item pertanyaan secara keseluruhan hasil analisis kepuasan pelanggan sudah bagus terutama kualitas layanan dan penanganan keluhan dan pengaduan, sedangkan analisis variabel fasilitas layanan melalui fasilitas layanan langsung kepada pelanggan dan fasilitas layanan penunjang memberikan pengaruh positif dan signifikan terhadap kepuasan pelanggan dan andil yang besar ditunjukan oleh layanan obat dengan tingkat validitas terbesar dibandingkan dengan layanan yang lain, sedangkan andil terendah terhadap kepuasan pelanggan ditunjukan oleh fasilitas toilet.

Lingkungan kerja layanan melalui lingkungan kerja layanan langsung kepada pelanggan memberikan pengaruh positif terhadap kepuasan pelanggan dan andil terbesar terhadap kepuasan pelanggan adalah kenyamanan pelayanan, hubungan dan komonikasi petugas pelayanan dengan pelanggan, dan andil terkecil terhadap kepuasan pelanggan adalah penanganan sampah dilingkungan layanan, sedangkan kondisi lingkungan kerja layanan yang diukur dengan kebisingan, polusi udara dan penerangan berpengaruh positif akan tetapi tidak signifiakan terhadap kepuasan pelanggan andil terbesar ketidakpuasan adalah kebisingan ini sejalan dengan kondisi Pusat Pelayanan Kesehatan Masyarakat dimana lokasinya di pinggir jalan raya yang ramai.

Fasilitas yang perlu mendapatkan perhatian oleh manajemen kinerja layanan adalah fasilitas tempat parkir dan fasilitas toilet pelanggan, sejalan dengan tempat parkir yang terbatas, sedangkan di lingkungan kerja dan pelayanan yang perlu mendapat perhatian oleh manajemen kinerja layanan adalah kebisingan dan penanganan sampah di lingkungan kerja pelayanan dan beberapa item yang telah menunjukan kinerja yang baik perlu dipertahankan atau di tingkatkan. 


\section{UCAPAN TERIMA KASIH}

Puji syukur kehadirat Tuhan YME dengan terselesainya penelitian ini, terima kasih kepada dr. Niswah Nilam Qanitah sebagai Kepala Puskesmas Leces dan staf Puskesmas Leces yang telah membantu dan memberikan kesempatan penelitian, terima kasih kepada Ibu Indah dan Ibu Susi sebagai koordinator survey dan petugas pembantu lapangan, terima kasih juga kepada semua pihak yang tidak disebutkan disini yang membantu dan ikut andil dalam kelancaran penelitian ini.

\section{DAFTAR PUSTAKA}

Afandi, P. (2018). Manajemen Sumber Daya Manusia Teori Konsep dan Indikator. Pekan Baru Riau: Zavana Pubishing.

Ali et al. (2016). The effect of physical environment on passenger delight and satisfaction: Moderating effect of national identity. Tourism Management, 57, 213-224. https://doi.org/10.1016/j.tourman.2016.06.004

Ansory dan Indrasari. (2018). Manajemen Sumber Daya Manusia. Sidoarjo: Indomedia Pustaka.

Azhar, \& R. (2018). Lingkungan Kerja Dan Implikasinya Terhadap Kepuasan Kerja Karyawan. $\begin{array}{llll}\text { Jurnal Pendidikan } \quad \text { Manajemen } & \text { Perkantoran, } & 3(2), & \end{array}$ https://doi.org/10.17509/jpm.v3i2.11816

Elfian, E., \& Ariwibowo, P. (2018). Pengaruh Kualitas Pelayanan terhadap Kepuasan Konsumen Bis Transjakarta di Terminal Kampung Melayu. Jurnal Dinamika Manajemen Dan Bisnis, l(2). https://doi.org/10.21009/jdmb.01.2.05

Gofur, A. (2019). Pengaruh Kualitas Pelayanan Dan Harga Terhadap Kepuasan Pelanggan. Jurnal Riset Manajemen Dan Bisnis (JRMB) Fakultas Ekonomi UNIAT, 4(1), 37-44.

Hermanto. (2016a). Pengaruh Penerapan ISO 9001:2008 Terhadap Kepuasan Pelanggan Pada Balai Pengobatan PT. Kertas Leces di Probolinggo. Jurnal Ilmiah Ecobuss, 4(1), 30-39. Retrieved from https://ejournal.upm.ac.id/index.php/ecobuss/article/view/210

Hermanto, H. (2016b). Pengaruh Kejelasan Pelayanan, Kedisiplinan Petugas Pelayanan, Kecepatan Pelayanan Dan Infrastruktur Terhadap Kepuasan Masyarakat. Prosiding Seminar Nasional, 1(1), 301-310. Retrieved from https://jurnal.unej.ac.id/index.php/prosiding/article/view/3666

Herokholiqi, dan C. (2018). Analisa Kualitas Pelayanan Bioskop Terhadap Kepuasan Dan Loyalitas Pelanggan Menggunakan Metode Structural Equation Modeling (Sem). Spektrum Industri, $\quad$ 16(1), $\quad 9-17 . \quad$ Retrieved $\quad$ from http://journal.uad.ac.id/index.php/Spektrum/article/view/9776/4730

Hidayat, \& S. (2018). Service Quality dan Implikasinya Terhadap Kepuasan Pelanggan. Jurnal Riset Bisnis Dan Investasi, 3(2), 13. https://doi.org/10.35697/jrbi.v3i2.930

Ismail, A. et all. (2001). Service quality and customer loyalty in telecommunication sector, $18(\mathrm{M})$, 71-81. https://doi.org/10.9744/jmk.18.1.71

ISO 9001. (2015). Sistem Manajemen Mutu-Persyaratan (ISO 9001:2015 IDT) ICS 03.120.10. Jakarta: BSN (Badan Standarisasi Nasional).

Jiang, L., Gan, C., Kao, B., Zhang, Y., Zhang, H., \& Cai, L. (2009). Consumer Satisfaction with Public Health Care in China. Journal of Social Sciences, 5(3), 223-235. https://doi.org/10.3844/jssp.2009.223.235

Lestary, \& H. (2018). Pengaruh Lingkungan Kerja Terhadap Kinerja Karyawan. Jurnal Riset Bisnis Dan Investasi, 3(2), 94. https://doi.org/10.35697/jrbi.v3i2.937

Meesala, A., \& Paul, J. (2016). Service quality, consumer satisfaction and loyalty in hospitals: Thinking for the future. Journal of Retailing and Consumer Services, 40(October 2015), 261-269. https://doi.org/10.1016/j.jretconser.2016.10.011

Miswanto, \& A. (2017). The Influence Of Service Quality And Store Atmosphere, 19(2), 106-111. https://doi.org/10.9744/jmk.19.2.106

Ningsih, \&, \& Segoro. (2014). The Influence of Customer Satisfaction, Switching Cost and Trusts in a Brand on Customer Loyalty - The Survey on Student as im3 Users in Depok, Indonesia. Procedia - Social and Behavioral Sciences, 143, 1015-1019. https://doi.org/10.1016/j.sbspro.2014.07.546 
Permenkes No. 71. (2013). Peraturan Menteri Kesehatan Republik Indonesia Tentang Pelayanan Kesehatan pada Jaminan Kesehatan Nasional.

Priansa, D. J. (2017). Komunikasi Pemasaran Terpadu Pada Era Media Sosial. Bandung: CV Pustaka Setia.

Rahayuningsih, et al. (2017). Pengaruh Kompensasi Dan Lingkungan Kerja Terhadap Kepuasan Kerja Guru Smp Negeri Di Sub Rayon 02 Pecangaan Kabupaten Jepara. Jurnal Manajemen Pendidikan (JMP) (2017) 5(3), 5(3), 331-345.

Ratihpratiwi, A. \&. (2019). Pengaruh Kompensasi dan Lingkungan Kerja Terhadap Kepuasan Kerja Karyawan PT. Tor Ganda Medan. Tijarah Ekonomi Dan Bisnis Islami, 1(17), 0-13.

Salgiarti \& Suryani. (2017). Pengaruh Lingkungan Kerja Fisik, Fasilitas Kerja dan Kompetensi Pegawai terhadap Sistem Pengelolaan Arsip Dikantor Kelurahan se-Kecamatan Cilacap Utara. Economic Education Analysis Journal, 6(2), 339-351. Retrieved from http://journal.unnes.ac.id/sju/index.php/eeaj

Sari, U. P. (2016). Pengaruh Fasilitas, Lingkungan Kerja Dan Motivasi Terhadap Kinerja Pegawai Di Kantor Camat Sangatta Selatan Kabupaten Kutai Timur. EJournal Pemerintahan Integratif, 4(4), 505-519.

Sedarmayanti. (2011). Tata Kerja dan Produktivitas Kerja Suatu Tinjauan dari Aspek Argonomi atau Kaitan Antara Manusai dengan Lingkungan Kerjanya. Bandung: CV Mandar Maju.

Setyawan, D. B. (2017). Pengaruh Motivasi, Stres Kerja, Lingkungan Kerja Fisik dan Lingkungan Kerja Non Fisik Terhadap Kinerja Karyawan. Seminar Nasional Dan The 4th Call For Syariah Paper (SANCALL) Peran Profesi Akuntansi Dalam Penanggulangan Korupsi, 4.

Soekiyono. (2017). Analisis Faktor Yang Memperanguruhi Kepuasan Pasien Badan Pelayanan Jaminan Sosial (Bpjs) Kesehatan Pada Rumah Sakit Jabodetang, 11(1), 50-60.

Sofyan dkk. (2013). Pengaruh fasilitas dan kualitas pelayanan terhadap loyalitas, melalui kepuasan konsumen sebagai variabel intervening pada Star Clean Car Wash Semarang. Diponegoro Journal of Social and Politic, 1-12.

Sudiarditha, et al. (2016). Pengaruh Lingkungan Kerja Dan Motivasi Terhadap Kinerja. Jurnal Manajemen, 20(2), 1-5.

Sujarweni, V. W. (2014). Metodologi Penelitian Bisnis \& Ekonomi. (Pustaka Baru Press, Ed.). Yogyakarta.

Sulistiawan, et al. (2017). Pengaruh budaya organisasi dan lingkungan kerja terhadap kinerja pegawai. Kinerja, 14(2), 61-69. Retrieved from http://journal.feb.unmul.ac.id/index.php/KINERJA/article/view/2480/338

Tjiptono \& Chandra. (2011). Service, Quality \& Satisfaction (3rd ed.). Yogyakarta: Andi.

Tjiptono \& Chandra. (2015). Strategi Pemasaran (4th ed.). Yogyakarta: Andi.

UU RI No.36. (2009). Undang Undang Republik Indonesia Nomor 36 Tentang Kesehatan.

Virgana. (2014). Kepuasan kerja, kepemimpinan, lingkungan, dan motivasi kerja pegawai dinas pendidikan. Jurnal Ilmu Pendidikan, 20(2), 150-155.

Warsito, B. (2008). Pengaruh Imbalan dan Lingkungan Kerja Terhadap Kepuasan Kerja. Jurnal Ekonomi Modernisasi, 4(3), 184-193.

Widodo, A. S. (2016). Analisis Pengaruh Kualitas Pelayanan Terhadap Kepuasan Pelanggan Pada Hotel Arista Palembang. IQTISHAD. Jurnal Sosial Ekonomi, 16(2), 59-67. https://doi.org/10.13140/RG.2.2.17882.59844 